\title{
COLOMBIA: THE RERUN AS A LEADING PLAYER IN TIMES OF PANDEMIC DOI: https://doi.org/10.7764/obitel.21.E.5
}

\begin{abstract}
Authors:
Fernando Aranguren Díaz: https://orcid.org/0000-0001-5565-4536 Borys Bustamante Bohórquez: https://orcid.org/0000-0001-7986-1441 Hernán Javier Riveros Solórzano: https://orcid.org/0000-0002-1185-7603

Team:

Diana María Lozano Prat, María Teresa Garzón Carreño, Gloria Yuliana Sepúlveda, Daniela Buitrago Pastrana, Juan Felipe Nieto Molina, Zulma Velandia Velandia, Olga Milena Forero Contreras
\end{abstract}

\section{Introduction}

The year 2020 was completely atypical on a global level and will surely go down in history as a period of crisis, uncertainties, and profound changes in the habits of life and societies around the world. Thus, after the declaration of a pandemic in relation to the Sars Cov 2 virus and the COVID 19 disease, the globe faced an unexpected challenge represented in the declaration of quarantines, confinements and a whole set of public health measures in the midst of the anguish which took place 
before the increase in occupation of Intensive Care Units, the collapse of hospitals and, despite current high levels of technological advances, the lack of knowledge regarding measures for the containment, prevention and management of the virus. In the Colombian context, after the first case was detected on March 6, 2020, a system of measures led by different government decrees and regulations came into operation, such as decree 457 of March 22, 2020, decree 637 of May 6, 2020 and decree 417 of March 17, 2020, in which not only was the State of Emergency declared at the national level but also different strategies were generated such as generalized confinement, restrictions on mobility and, at the same time, different productive, educational and social activities were suspended.

The small screen was not alien to the situation, on the contrary, television grills began to be populated with long-term information programs and, at the same time, fiction became the companion of Colombian households, as well as a kind of escape from the counts of deceased and infected reported daily. Similarly, platforms such as Netflix, Amazon Prime and the arrival at the end of the year of Disney + together with systems such as $\mathrm{HBO}+$ and spaces such as Claro Video, also became alternatives to accompany the moments of anguish and uncertainty of people confined in their houses. Hence, after the debate on the percentage of screen time for national productions, the appearance of reruns as protagonists of prime time was allowed not only because they appeal to nostalgia, but also for that dose of humor, wit and entertainment that allowed viewers to leave aside, at times, the complexity of an epidemiological and social reality in which, along with the growth of the peaks of the disease, red flags also proliferated in the windows as a symbol of the economic crisis of the most vulnerable. 
Thus, 2020 was presented in Colombia as a year of confinement, as in the rest of the world, but also, in the case of television fiction, a period to revisit the productions of other times, both on the small screen as in television streaming systems, generating such curious phenomena such as that_Pasión de Gavilanes was the most watched fiction both on national television and on Netflix at the same time. And parallel to this, the flourishing of new productions and web series as a refuge for actors, actresses and even a new setting for theater and an industry such as the audiovisual industry that, along with others, was entering in an agonizing recess.

\section{The audiovisual context of Colombia in 2020}

\subsection{Open television in Colombia}

Open television in Colombia is made up of five national channels distributed as follows:

\section{Chart 1. National Open Television Networks / Channels in Colombia}

\begin{tabular}{|c|c|}
\hline Private broadcast / channel (3) & Public broadcast / channel (2) \\
\hline Caracol & Señal Colombia \\
\hline R.C.N. & Canal Institucional \\
\hline Canal Uno & \\
\hline \multicolumn{2}{|c|}{ TOTAL CHANNELS $\mathbf{5}$} \\
\hline
\end{tabular}

Source: Obitel Colombia

In times of pandemic, Caracol assumes a leadership position again among the audiences, reinforced by informative spaces and the 
abundance of reruns that managed to position themselves primarily in prime time during 2020.

Graph 1. TV Rating and Share by Station

\begin{tabular}{l|r|r|r|}
\hline \multicolumn{1}{c|}{ Channel } & $\begin{array}{c}\text { Home Rating } \\
\text { (\%) }\end{array}$ & $\begin{array}{c}\text { Total TV } \\
\text { Share (\%) }\end{array}$ & $\begin{array}{c}\text { Open TV } \\
\text { Share (\%) }\end{array}$ \\
\hline Caracol & 14,5 & 45,1 & 51,6 \\
\hline R.C.N. & 11,3 & 35,1 & 30,4 \\
\hline Canal Uno & 3,1 & 9,6 & 10,6 \\
\hline Señal & 2,9 & 9 & 3,32 \\
\hline Institucional & 0,4 & 1,2 & 0,75 \\
\hline TOTAL & $\mathbf{3 2 , 2}$ & $\mathbf{1 0 0}$ & $\mathbf{9 6 , 6}$ \\
\hline
\end{tabular}

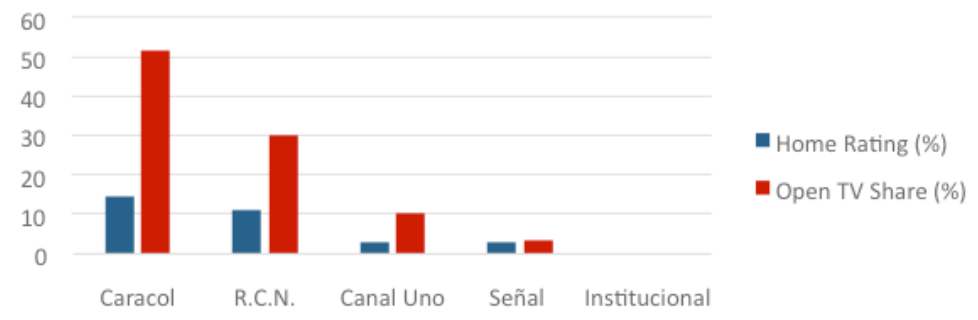

Source: Obitel Colombia / Kantar Ibope Media Colombia

The previous graph shows the considerable growth in both rating and share in the case of Caracol compared to $\mathrm{RCN}$, mainly due to the high presence of reruns and the ability to attract audiences, this was achieved through informational spaces, primarily the news, which increased the duration of its emissions in times of pandemic. This way, the evening news not only became the program with the highest audience, but also the drag element towards the prime time which was covered by productions that were successful in other time frames such as Pasión de Gavilanes and Pedro El Escamoso. 
Graph 2: Genres and Hours Broadcasted in TV Programming.

\begin{tabular}{|l|r|r|}
\hline \multicolumn{1}{|c|}{ Genres Broadcast } & $\begin{array}{c}\text { Screening } \\
\text { hours }\end{array}$ & \multicolumn{1}{c|}{$\%$} \\
\hline Fiction & $21.317: 30$ & 32,8 \\
\hline Information & $20.870: 30$ & 32,2 \\
\hline Sports & $5.237: 20$ & 8,2 \\
\hline Entertainment & $10.355: 30$ & 15,9 \\
\hline Religion & $630: 30$ & 0,9 \\
\hline Political & $770: 20$ & 1,1 \\
\hline Educational & $870: 20$ & 1,3 \\
\hline Other & $4.987: 25$ & 7,6 \\
\hline TOTAL & $\mathbf{6 5 . 0 3 6 : 2 5}$ & $\mathbf{1 0 0}$ \\
\hline
\end{tabular}

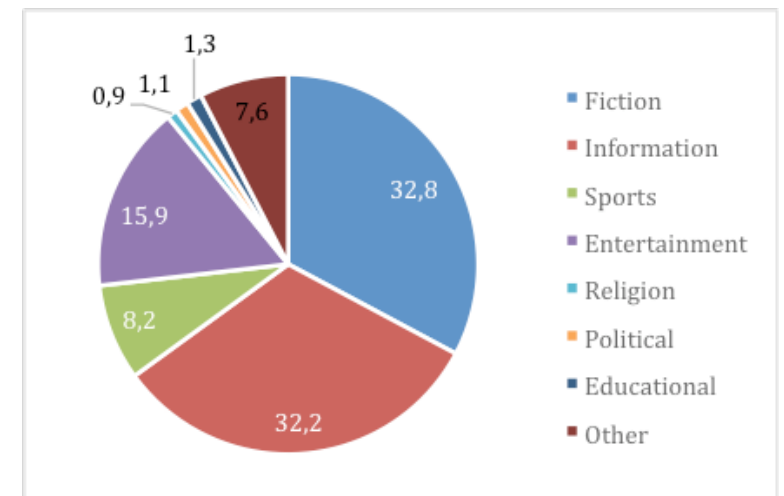

Source: Obitel Colombia

Because of the global situation caused by the pandemic, 2020 's television offer was filled with news and fictions. This since the sporting, musical and cultural events were not held for much of the year, leaving that television space to fiction and especially to information spaces that became the companions of a large portion of the audience's day; which was reflected in the increase of the news broadcasts which became spaces of more than three hours long. 


\subsection{Pay TV and VoD platforms in Colombia}

During the global situation experienced in 2020 where extended quarantines were a common, if not total, phenomenon, pay television platforms and videos on demand became the main entertainment bet for consumers. Thus, according to a report developed by Sherlock Communications on the consumption of PayTV in Latin America, 48\% of Colombians subscribed to one of the available streaming platforms, while $20 \%$ decided to access two of these services. The sample shows the increase in these entertainment systems that, despite the economic difficulties caused by the pandemic, are an indispensable mass consumer product in homes.

Added to this phenomenon are the possibilities of exclusive content platforms offered by cable operators, mainly Claro Video, a service that allows all subscribers of this company to access series and movies that are not offered in the traditional service. On the other hand, for 2020 the arrival in Colombia of the Disney+ platform stands out, which generated a high demand for subscriptions under the premise of finding exclusive entertainment content, from the classics to the series developed exclusively for this space. Amazon Prime also spread as another coveted option, however, Netflix continues to be the preferred platform in the country.

\section{Chart 2. Pay television channels in Colombia}

\begin{tabular}{|l|}
\hline \multicolumn{1}{|c|}{$\mathbf{1 0}$ most viewed Pay TV channels in } \\
\hline 1) Fox (Series Movies), 2) TNT \\
(Series Movies), 3) Space (Series \\
Movies), 4) HBO (Series Movies), \\
5) Golden (Series Movies), 6) Fox, \\
7) Sports (Sports), 8) ESPN (Sports) \\
9) WIN Sports (Sports), 10) NTN 24 \\
(News), 11) Cable noticias (News) \\
\hline TOTAL: 8 news channels \\
\hline
\end{tabular}


In Colombia there is a very particular situation, and it is that channels included in payment packages stand out, mainly those related to sporting and fiction content. This is directly related to Colombians' taste for sports content, mainly soccer. During 2020, controversy broke out when the WinSports+ channel became the only channel that broadcasted all the matches of the Colombian professional soccer league, since in general, the costs were considered high by users, and it also opened the discussion of what should be part of open television.

\section{Chart 3. VoD in Colombia}

\begin{tabular}{|c|c|}
\hline Top Active VoD Platforms in 2020 & Total \\
\hline $\begin{array}{l}\text { Netflix, Disney+, Prime (Amazon), } \\
\text { HBOGo (Warner Media), FOX+ } \\
\text { (Disney). }\end{array}$ & 5 \\
\hline TOTAL & 5 \\
\hline
\end{tabular}

Source: Obitel Colombia

During the year 2020 in Colombia, the rising curve in the consumption of streaming platforms was maintained, mainly of the Netflix platform, which has had such a reception that it has remained in the first place of consumption in the country and has led to the establishment of new marketing dynamics, even including the possibility of consuming this service in a prepaid mode through cards that are sold in different technology and chain stores. On the other hand, although there are no official sources on this modality, there are possibilities in social networks for the commercialization of informal accounts in which the costs of access to this and other streaming platforms are much lower.

Within the dynamics of the country, it is also highlighted that there are open television channels that offer additional services that can be accessed as a paid service, such is the case of the Caracol Play VoD system which is part of the Caracol Televisión channel that works 
as an open channel. Added to this modality is the one where consumers have the possibility of accessing additional services such as the HBO and FOX + networks as part of the benefits for acquiring pay television plans, an example of this is Claro Video, a platform that works as a benefit for users of Claro's pay television.

\subsection{Television fiction independent production companies}

The phenomenon presented during the quarantine of 2020 in the world leaves a trend in the behavior of these companies that, within the new possibilities, have advanced towards the elaboration of productions with a load of creativity and new ways of developing the process. Among the trends that were evidenced in the case of Colombia, are those from which independent production companies developed projects related to the development of pieces suitable for broadcasting through free platforms, especially YouTube. Ideas arose which allowed those situations that families were being part of in the day-to-day life of this time to be shown on screen, samples of this are found in series such as: "Una familia en cuarentena" or "Aisla2 en cuarentena" and products developed by some YouTubers focused on this topic.

From this exercise, productions also emerged that, taking advantage of the historical moment, together with large companies and production companies, worked together on miniseries to be broadcast on different digital media and from which the brand was advertised, but the narrative dynamics of fiction productions were maintained. One case to highlight from this exercise is the series "Vidas posibles", broadcast on its own website as a result between the French brand of vehicles Renault and the producer Fox Colombia. Considering the creative work, a result of the quarantine, it can be deduced that although the effects on the television industry, in general, were very negative, there were examples of new dynamics that set the process and allowed giving life to different and entertaining productions for the public. 


\subsection{Sources of financing for the audiovisual sector}

The year 2020 was a particularly difficult year for all economic sectors directly affected by the extended quarantines and the effects of the global pandemic, however, some sectors were also favored given the confinement conditions in which consumers found themselves. A clear example of this is the subscription television sector, which according to flash data issued by the Communications Regulatory Commission (CRC) on April 12, 2021, had a strong boost in the consumption of its services, "during the year 2020, the revenues associated with the subscription television service reached COP $\$ 3.26$ billion, which represented a growth of $2.13 \%$ compared to 2019 . On the other hand, the subscribers of this service reached 6.06 million, presenting an increase of more than 131 thousand subscribers when compared to 2019". Although these figures apply exclusively to basic plans, an increase in access to these services is evidenced. Finally, the $6.56 \%$ of investment made in pay TV registrations correspond to premium services.

On the other hand, the Ibope report regarding television consumption in Colombia, reflects that during 2020 an investment in advertising of $\$ 4,613,625,671$ was made on open television channels, taking the first place of investment in advertising the broadcast of Caracol Televisión prime time with a sum of $\$ 270,891,529$. Other sources of financing for Colombian television are related to the access to exclusive content systems of open television channels and new trends in fiction-related productions carried out in alliance between large commercial brands and production companies that take advantage of the specific situation of the pandemic.

\subsection{Communication policies}

Law 182 of 1995 came into force on January 20, 1995, which regulated the television service and formulated policies for its develop- 
ment. However, due to the situation generated by covid-19, the national channels were forced to cancel and stop filming and productions, due to the confinement measures decreed by the National Government. To aggravate the situation, the Decree 516 of April 4, 2020, was issued on April 4, 2020, in which the share of the national programming screen was reduced to $20 \%$. The addition of a second paragraph to article 33 of Law 182 of 1995, established that, according to the duration of the state of emergency, the minimum percentages of national programming would be $20 \%$ in the prime-time slot, a considerable reduction for an industry subjected to the rigors of the pandemic.

The above situation led the country's audiovisual sector to wonder why in times of emergency, when work is scarce, support and incentives for audiovisual production in the country are reduced? Discontent did not take long and organizations such as the ACA (Colombian Association of Actors) and the ACTV (Colombian Association of Audiovisual Industry Workers), stated that the reduction of participation in the screen quota to $20 \%$, reduced not only national productions, but the income that librettists, producers, and actors received in times of confinement due to the retransmission of national productions, thanks to laws such as Pepe Sánchez or Fanny Mikey. Among the different unions of the audiovisual sector, a generalized discontent was promoted, against the decree issued by the Ministry of Information and Communication Technologies (MinTIC) headed by Minister Sylvia Constaín, who stated that the measure taken was temporary, however, for the different unions this measure ignored the needs of the sector. Thus, a movement was born against the Duque government's "orange economy" program, which under the hagshtag \#MuchaPantallaPocaNaranja mobilized different actors, producers, and librettists in the country ${ }^{1}$. This finally led to the so-called screen quota being

1 Gaceta (2020). Sigue polémica por decreto que baja cuota de producciones nacionales en la tv, El País.com, April 26, 2020, consulted April 11, 2021. Available in https://www. elpais.com.co/cultura/gaceta/la-tv-colombiana-esta-rota-asi-va-la-polemica-por-el-decretoque-baja-la-cuota-de-pantalla.html 
maintained, which resulted in the appearance of a large group of reruns that became the protagonists of prime time.

\subsection{Digital and mobile connectivity infrastructure}

Among the technological changes that the country has experienced in recent decades, is the implementation of Digital Terrestrial Television - DTT which, through an external decoder connected to old televisions or an internal in more recent models, made it possible to access high-definition television in $80 \%$ of the national territory by 2020 , according to figures issued by MinTIC. The webpage tdtparatodos.tv, defines December 31, 2021, as the deadline for the implementation of DTT in $100 \%$ of the national territory since analog broadcasts will be suspended. ${ }^{2}$

Another situation that has been presenting transformations in the ICT sector is related to the provision of mobile and internet services. In this regard, the Communications Regulation Commission points out that there are 8 companies in charge of this service in the country, these are: Avantel, Claro, ETB, Éxito Móvil, Movistar, Tigo, Uffmovil and Virgin Mobile. According to the Opensignal report published in January 2021, of the mentioned companies, Tigo was positioned as the best company to offer connectivity services by achieving 6 of the 7 recognitions granted by this mention, surpassing Claro, who has dominated the scene in recent years. ${ }^{3}$

In this panorama, there is the emergence of a new competitor within the telecommunications market called "Wom" that by 2020 promised to consolidate itself as one of the best connectivity companies in the country. According to Chris Bannister, director of Wom for

2 Tdtparatodos.tv. 31 de diciembre de 2022 es la fecha límite para el cese de emisiones analógicas de televisión, $\square$ consulted April 11, 2021. Available in https://www.tdtparatodos. tv/noticias/colombia-avanza-proceso-migracion-tdt

3 Portafolio (2021). ¿Cuál es hoy el operador con mejor internet móvil en Colombia?, 04 de febrero de 2021, consulted April 11, 2021. Available in https://www.portafolio.co/ negocios/empresas/cual-es-el-operador-de-telefonia-con-mejor-internet-movil-en-colombia-548832 
Colombia, an investment of more than a billion dollars is expected during the next 5 years in network coverage, technology, and customer service. However, among the different controversies that the arrival of this new operator has endured, the competitiveness outlook is discouraging, since Claro is the mobile service provider that accumulates the most lines in the country with 31.2 million lines, followed by Movistar with 15.9 million and Tigo, with 11.8 million. ${ }^{4}$

\section{Analysis of the year}

Table 1. Fictions exhibited in 2020 (national and imported; premiere, reruns, and co-productions).

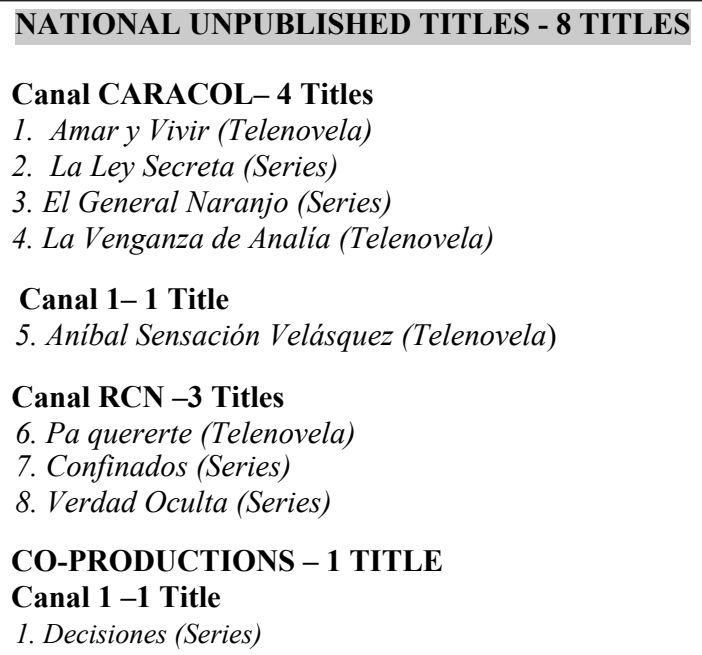

1. Decisiones (Series)

\section{OBITEL UNPUBLISHED IMPORTED TILES - 4 TITLES}

\section{Canal CARACOL 3 Titles}

1. Cuna de Lobos (Telenovela-Mexico)

2. Imperio de Mentiras (Telenovela- Mexico)

3. La Usurpadora (Telenovela-Mexico)

\section{Canal RCN 1 Title}

4. Te doy la Vida (Telenovela-México)

4 El Tiempo (2020). Wom, el nuevo operador que llega a dinamizar la telefonía móvil, El Tiempo.com, 03 de noviembre de 2020, consulted April 11, 2021. Available in https:// www.eltiempo.com/tecnosfera/novedades-tecnologia/wom-el-nuevo-operador-que-llega-adinamizar-la-telefonia-movil-en-colombia-546711 


\section{NOT OBITEL UNPUBLISHED IMPORTED TILES - 0}

Does not apply

\section{RERUN TITLES - 35 TITLES}

1. Allá te Espero (telenovela)

2. Amor en Custodia (telenovela)

3. Contra las Cuerdas (telenovela)

4. Doña Bella (telenovela)

5. En Tierras Salvajes (telenovela)

6. Enfermeras (telenovela)

7. La Traicionera (telenovela)

8. Chepe Fortuna (telenovela)

9. Cuando me Enamoro (telenovela)

10. El Inútil (telenovela)

11. Francisco el Matemático (telenovela)

12. Soy tu Dueña (telenovela)

13. Teresa (telenovela)

14. 3 milagros (telenovela)

15. Amor Sincero (telenovela)

16. Diomedes Cacique de la Junta (telenovela)

17. El Joe la Leyenda (telenovela)

18. Hasta que la Plata nos Separe (telenovela)

19. La Hija del Mariachi (telenovela)

20. Los Reyes (telenovela)

21. Yo soy Betty la Fea (telenovela)

22. Abismo de Pasión (telenovela)

23. Corazón Indomable (telenovela)

24. El Cuerpo del Deseo (telenovela)

25. La que no podía Amar (telenovela)

26. Un refugio para el Amor (telenovela)

27. Bellas Calamidades (telenovela)

28. Cuna de Lobos (telenovela)

29. La que no Podía Amar (telenovela)

30. Lo que la Vida me Robó (telenovela)

31. Rubi (telenovela)

32. La Nocturna (telenovela)

33. Pasión de Gavilanes (telenovela)

34. Pedro el Escamoso (telenovela)

35. Rafael Orozco el Ídolo (series)

TOTAL OF NATIONAL UNPUBLISHED TITLES: 8

TOTAL OF OBITEL UNPUBLISHED TITLES: 4

TOTAL OF UNPUBLISHED TITLES (NATIONAL AND OBITEL): 12

Source: OBITEL Colombia / Kantar Ibope Media Colombia 
In 2020 the number of reruns increased considerably compared to unpublished titles, largely due to the regulations of national production's screen quota and that, given the impossibility of recording and production, this meant that some fictions would cease to be broadcasted since new episodes are not able to be produced (this is the case of Pa quererte) and television grills will be filled with content from other times.

Table 2: Premiere fiction in 2020: Countries of origin

\begin{tabular}{|l|r|r|r|r|r|r|}
\hline \multicolumn{1}{|c|}{ Country } & Titles & \multicolumn{1}{c|}{$\%$} & \multicolumn{1}{c|}{ Episodes } & \multicolumn{1}{c|}{$\%$} & \multicolumn{1}{c|}{ Hours } & \multicolumn{1}{c|}{$\%$} \\
\hline NATIONAL (total) & $\mathbf{8}$ & $\mathbf{6 6 , 7}$ & $\mathbf{3 3 6}$ & $\mathbf{6 0 , 2}$ & $\mathbf{2 7 0 : 4 5 : 0 0}$ & $\mathbf{6 9 , 9}$ \\
\hline OBITEL COUNTRIES (total) & $\mathbf{4}$ & $\mathbf{3 3 , 3}$ & $\mathbf{2 2 2}$ & $\mathbf{3 9 , 8}$ & $\mathbf{1 1 6 : 3 0 : 0 0}$ & $\mathbf{3 0 , 1}$ \\
\hline Argentina & 0 & 0,0 & 0 & 0,0 & $0: 00: 00$ & 0,0 \\
\hline Brazil & 0 & 0,0 & 0 & 0,0 & $0: 00: 00$ & 0,0 \\
\hline Chile & 0 & 0,0 & 0 & 0,0 & $0: 00: 00$ & 0,0 \\
\hline Colombia & 8 & 66,7 & 336 & 60,2 & $270: 45: 00$ & 69,9 \\
\hline Ecuador & 0 & 0,0 & 0 & 0,0 & $0: 00: 00$ & 0,0 \\
\hline Spain & 0 & 0,0 & 0 & 0,0 & $0: 00: 00$ & 0,0 \\
\hline USA (Hispanic production) & 1 & 8,3 & 0 & 0,0 & $0: 00: 00$ & 0,0 \\
\hline Mexico & 4 & 33,3 & 222 & 39,8 & $116: 30: 00$ & 30,1 \\
\hline Peru & 0 & 0,0 & 0 & 0,0 & $0: 00: 00$ & 0,0 \\
\hline Portugal & 0 & 0,0 & 0 & 0,0 & $0: 00: 00$ & 0,0 \\
\hline Uruguay & 0 & 0,0 & 0 & 0,0 & $0: 00: 00$ & 0,0 \\
\hline Venezuela & 0 & 0,0 & 0 & 0,0 & $0: 00: 00$ & 0,0 \\
\hline CO-PRODUCTIONS (total) & $\mathbf{1}$ & $\mathbf{0 , 0}$ & $\mathbf{0}$ & $\mathbf{0 , 0}$ & $\mathbf{0 : 0 0 : 0 0}$ & $\mathbf{0 , 0}$ \\
\hline Colombian Co-productions & $\mathbf{0}$ & $\mathbf{0 , 0}$ & $\mathbf{0}$ & $\mathbf{0 , 0}$ & $\mathbf{0 : 0 0 : 0 0}$ & $\mathbf{0 , 0}$ \\
\hline Co-productions between Obitel countries & $\mathbf{0}$ & $\mathbf{0 , 0}$ & $\mathbf{0}$ & $\mathbf{0 , 0}$ & $\mathbf{0 : 0 0 : 0 0}$ & $\mathbf{0 , 0}$ \\
\hline GRAND TOTAL & $\mathbf{1 2}$ & $\mathbf{1 0 0 , 0}$ & $\mathbf{5 5 8}$ & $\mathbf{0 , 0}$ & $\mathbf{3 8 7}: 15: 00$ & $\mathbf{1 0 0 , 0}$ \\
\hline
\end{tabular}

Source: OBITEL Colombia / Kantar Ibope Media Colombia

With regards to the countries of origin, the growth of fictions in co-production and a greater presence of Colombian productions is evident, something largely mediated by the application of the screen quota, which was full of national production from other times. 
Table 3: Formats of national and Ibero-American fiction

\begin{tabular}{|c|c|c|c|c|c|c|c|c|c|c|c|c|}
\hline \multirow{2}{*}{ Format } & \multicolumn{6}{|c|}{ National } & \multicolumn{6}{|c|}{ Ibero-American } \\
\hline & Titles & $\%$ & $\mathbf{E}$ & $\%$ & $\mathbf{H}$ & $\%$ & Titles & $\%$ & $\mathbf{E}$ & $\%$ & $\mathbf{H}$ & $\%$ \\
\hline Telenovela & 25 & 67,6 & 2946 & 83,0 & 2482:00:00 & 75,3 & 21 & 60,0 & 2440 & 73,0 & $1854: 34: 48$ & 0,6 \\
\hline Series & 12 & 32,4 & 604 & 17,0 & $815: 15: 48$ & 24,7 & 14 & 40,0 & 902 & 27,0 & 1249:37:00 & 0,4 \\
\hline Miniseries & 0 & 0,0 & 0 & 0,0 & 0:00:00 & 0,0 & 0 & 0,0 & 0 & 0,0 & 0:00:00 & 0,0 \\
\hline TV Movie & 0 & 0,0 & 0 & 0,0 & $0: 00: 00$ & 0,0 & 0 & 0,0 & 0 & 0,0 & 0:00:00 & 0,0 \\
\hline Unitary & 0 & 0,0 & 0 & 0,0 & 0:00:00 & 0,0 & 0 & 0,0 & 0 & 0,0 & 0:00:00 & 0,0 \\
\hline Docudrama & 0 & 0,0 & 0 & 0,0 & 0:00:00 & 0,0 & 0 & 0,0 & 0 & 0,0 & 0:00:00 & 0,0 \\
\hline $\begin{array}{l}\text { Other (soap } \\
\text { opera, etc.) }\end{array}$ & 0 & 0,0 & 0 & 0,0 & $0: 00: 00$ & 0,0 & 0 & 0,0 & 0 & 0,0 & $0: 00: 00$ & 0,0 \\
\hline Total & 37 & 100,0 & 3550 & 100,0 & 3297:15:48 & 100,0 & 35 & 100,0 & 3342 & 100,0 & 3104:11:48 & 1,0 \\
\hline
\end{tabular}

Source: OBITEL Colombia/ Kantar Ibope Media Colombia

In the analysis of national and Ibero-American premieres, telenovelas prevail as protagonists of the television grill, mainly because of the prominence of the rerun that reflects a historical moment in which this was the predominant format in fiction and, the dominant panorama of the series in recent years was beginning to emerge.

Table 4: The ten most watched titles on open television

\begin{tabular}{|c|l|l|l|l|r|l|r|r|}
\hline \multicolumn{2}{|c|}{ Title } & Channel & $\begin{array}{l}\text { Production } \\
\text { company }\end{array}$ & Format/genre & $\begin{array}{c}\text { No. of } \\
\text { ep (in } \\
\mathbf{2 0 2 0}\end{array}$ & $\begin{array}{c}\text { Time } \\
\text { zone }\end{array}$ & Rating & Share \\
\hline 1 & Pasión de Gavilanes & Caracol & Caracol & Telenovela & 188 & Prime & 14,26 & 43,14 \\
\hline 2 & $\begin{array}{l}\text { La venganza de } \\
\text { Analía }\end{array}$ & Caracol & Caracol & Telenovela & 53 & Prime & 12,82 & 36,22 \\
\hline 3 & Amar y vivir & Caracol & Caracol & Telenovela & 69 & Prime & 11,85 & 34,58 \\
\hline 4 & Pedro el escamoso & Caracol & Caracol & Telenovela & 160 & Prime & 11,30 & 40,88 \\
\hline 5 & Pa Quererte & RCN & RCN & Telenovela & 137 & Prime & 11,26 & 18,87 \\
\hline 6 & Enfermeras & RCN & RCN & Telenovela & 159 & Prime & 10,53 & 22,59 \\
\hline 7 & $\begin{array}{l}\text { Rafael Orozco, } \\
\text { El Idolo }\end{array}$ & Caracol & Caracol & Series & 90 & Prime & 10,32 & 36,46 \\
\hline 8 & El General Naranjo & Caracol & $\begin{array}{l}\text { Telecolombi } \\
\text { a }\end{array}$ & Series & 52 & Prime & 9,86 & 36,78 \\
\hline 9 & Amor Sincero & RCN & RCN & Telenovela & 81 & Prime & 9,17 & 24,41 \\
\hline 1 & 3 Milagros & RCN & RCN & Series & 70 & Prime & 8,3 & 24 \\
\hline \multicolumn{2}{|c|}{ Total productions: 10 } & & & Foreign productions: & \\
\hline
\end{tabular}


The high presence of reruns as the main protagonists in the rating is evident, which also allowed the telenovela to have relevance and position itself as the dominant format once again. However, among premiere fictions, Caracol's main role is once again central with the positioning of La Venganza de Analía above Pa Quererte and Enfermeras, which together were the only premiere fictions along with $E l$ General Naranjo to obtain a position among the 10 most viewed of 2020.

Table 5: Audience profile of the ten most viewed titles: gender, age, socioeconomic level

\begin{tabular}{|c|c|c|c|c|c|c|c|c|c|c|c|c|}
\hline & \multirow[b]{2}{*}{ Titles } & \multirow[b]{2}{*}{ Channel } & \multicolumn{2}{|c|}{ Gender \% } & \multicolumn{3}{|c|}{ Socioeconomic Level \% } & \multicolumn{5}{|c|}{ Age Range \% } \\
\hline & & & Women & Men & $\mathbf{A B}^{*}$ & $\mathrm{C}^{*}$ & $\mathbf{D E} *$ & $\begin{array}{l}4 \text { to } \\
11^{*}\end{array}$ & $\begin{array}{l}12 \text { to } \\
17^{*}\end{array}$ & $\begin{array}{l}18 \text { to } \\
24^{*}\end{array}$ & $\begin{array}{l}25 \text { to } \\
34^{*}\end{array}$ & $50+*$ \\
\hline 1 & \begin{tabular}{|l|} 
Pasión De \\
Gavilanes
\end{tabular} & Caracol & 48,48 & 38,92 & 42,86 & 48,01 & 47,40 & 118,07 & 76,6 & 84,49 & 85,8 & 39,6 \\
\hline 2 & \begin{tabular}{|l|} 
La \\
Venganza \\
De Analia \\
\end{tabular} & racol & 25,87 & 20,31 & 48,25 & 50,46 & 35,64 & 46,11 & 26,7 & 32,76 & 43,48 & 22,6 \\
\hline 3 & $\begin{array}{l}\text { Amar } Y \\
\text { Vivir }\end{array}$ & Carac & 36,67 & 32,94 & 33,12 & 39,56 & 38,76 & 6,99 & 11,2 & 4,19 & 5,15 & 5,7 \\
\hline 4 & \begin{tabular}{|l|} 
Pedro El \\
Escamoso
\end{tabular} & Caracol & 44,95 & 40,76 & 31,51 & 44,71 & 48,59 & 107,18 & 75,2 & 84,27 & 82,6 & 41,9 \\
\hline 5 & Pa Quererte & $\mathrm{RCN}$ & 15,43 & 14,49 & 19,00 & 16,47 & 11,35 & 17,97 & $\begin{array}{r}17,9 \\
7\end{array}$ & 17,97 & 17,97 & $\begin{array}{r}17,9 \\
7\end{array}$ \\
\hline 6 & Enfermeras & $\mathrm{R}$ & & 10,92 & 10 & 11,27 & 16,22 & 34,95 & 36,6 & 25,4 & 29,78 & 10,7 \\
\hline 7 & $\begin{array}{l}\text { Rafael } \\
\text { Orozco } \\
\text { El idolo }\end{array}$ & Caracol & 41,26 & 34,19 & 31,00 & 40,10 & 42,92 & 96,88 & 59,6 & 76,38 & 65,92 & 36,3 \\
\hline 8 & \begin{tabular}{|l|} 
El General \\
Naranjo
\end{tabular} & Caracol & 33,06 & 32,28 & 37,25 & 39,23 & 34,84 & 62,37 & 41,8 & 50,09 & 55,69 & 36,2 \\
\hline 9 & \begin{tabular}{|l|} 
Amor \\
Sincero
\end{tabular} & $\mathrm{RCN}$ & 24,03 & 18,97 & 29,44 & 20,15 & 7,64 & 20,51 & $\begin{array}{r}24,4 \\
1 \\
\end{array}$ & 24,78 & 20,31 & 21,2 \\
\hline 10 & 3 Milagros & $\mathrm{RCN}$ & 24,83 & 19,41 & 7,24 & 18,32 & 29,42 & 24,03 & 30,5 & 41,67 & 22,25 & 17,8 \\
\hline
\end{tabular}

Source: OBITEL Colombia / Kantar Ibope Media Colombia

An increase in spectators of all ages and economic conditions is observed. This is due to the increase in the hours in which they stay at home due to the conditions of preventive quarantine and little interest in carrying out activities other than following the plot of a telenovela which had been broadcasted at another time in the past. 


\section{Monitoring of VoD 2020}

The year 2020, for Colombia and other countries, was a juncture year due to the Covid-19 health emergency. This, summed to the high demand of connectivity, has led to transformations in content consumption, since the traditional way of viewing has been replaced, prioritizing access to other audiovisual entertainment platforms. Thus, digital audiences and new consumption patterns have increased thanks to the pandemic, which has further stimulated and promoted the use of Streaming platforms (Tuñon, 2021).

Therefore, a mode of entertainment as an alternative to pandemic confinement was primarily accessing streaming platforms. Thus, among the most watched are reality shows, contests, drama, and comedy (SEMANA, 2020). The main platforms in Colombia for 2020 are referenced in the following chart:

Chart 4. Main VoD platforms in 2020

\begin{tabular}{|l|c|}
\hline Top Active VoD Platforms in 2020 & Total \\
\hline $\begin{array}{l}\text { Netflix, Disney+, Prime (Amazon), } \\
\text { HBOGo (Warner Media), FOX+ } \\
\text { (Disney). }\end{array}$ & $\mathbf{6}$ \\
\hline TOTAL & $\mathbf{6}$ \\
\hline
\end{tabular}

Source: OBITEL Colombia

Even though the above are the 5 main platforms in Colombia, cable operators such as Claro with Claro Video and other large national networks such as Caracol Play also offer their VoD services. In addition, it is worth noting the public proposal that has been forging since 2015: RTVC Play. 


\subsection{VoD platforms market}

To pan over the magnitude of the VoD market in Colombia, it is necessary to understand that the pandemic has inevitably generated in the country, and in Latin America, an increase in the demand for streaming content. According to the Sherlock Communications study (2020), which finds the perceptions of 3,000 consumers from countries such as Brazil, Mexico, Argentina, Peru, and Chile, including Colombia. The latter represented $43 \%$ of respondents who said they see streaming as one of the best alternatives for quarantine. It is in this way that Colombia represents $36 \%$ of consumers who say they are dissatisfied with local channels, reason why $20 \%$ of Colombians indicated having subscribed to two different platforms and $24 \%$ are new subscribers to VoD platforms.

On the other hand, if one of the reasons why consumers prefer VoD or OTT services is considered, Disney + the most striking launch last year as mentioned, offered a range of content such as Lucasfilm and Marvel with popular programs such as The Mandalorian, Muppets Now, among others, while HBO Max had a launch with a lower profile, achieving an increase by presenting original programs such as Zack Snyder's Justice League and The Flight Attendant (ZEMOGA, 2020).

\subsection{VoD analysis in 2020: national and Ibero-American premiere fiction}

Considering that one of the most popular platforms after the Covid-19 pandemic was Netflix, it was possible to identify that the most viewed contents in Colombia were the reality shows Jugando con Fuego, El Piso es Lava and El Amor es Ciego, this in addition to action content such as Misión de Rescate, La vieja Guardia and Proyecto Power. Also, Colombians viewed more Korean content than in 2019. At the beginning of April, the most watched drama in the country was Milagro en la Celda. With regards to comedy, Chichipatos was the 
most popular, along with El Halloween de Hubie and Amor de calendario. Finally, the most viewed fantasy titles were Siempre Bruja and Locke \& Key. In conclusion, according to Netflix, 2020 in Colombia showed that the consumption of realities and action genre doubled, the visualization of Korean, Turkish and fantasy genre content tripled, and the consumption of the Romance genre increased by almost $300 \%$ (INFOBAE, 2020).

For this reason, table 6 examines the national and ibero-american fictions exhibited in 2020 in the most popular VoD systems and with the highest number of participations in Streaming entertainment productions.

Table 6. National and Ibero-American fictions exhibited in VoD systems in 2020.

\begin{tabular}{|c|c|c|}
\hline $\begin{array}{c}\text { NATIONAL } \\
\text { PREMIERE TITLES }\end{array}$ & $\begin{array}{l}\text { IBERO-AMERICAN } \\
\text { PREMIERE TITLES }\end{array}$ & CO-PRODUCTIONS \\
\hline $\begin{array}{l}\text { Netflix - } \mathbf{N}^{\circ} \text { national } \\
\text { titles } \\
\text { 1. Loco por vos (Movie) } \\
\text { 2. Chichipatos (Movie) } \\
\text { 3. Amar y vivir (Series) } \\
\text { 4. Siempre bruja Season } 2 \\
\text { (Series) } \\
\text { 5. El robo del siglo } \\
\text { (Series) } \\
\text { Caracol Play - } \mathbf{N}^{\circ} \\
\text { national titles } \\
\text { 1. La venganza de Analia } \\
\text { (Series) } \\
\text { 2. La nocturna } 2 \text { (Series) }\end{array}$ & $\begin{array}{l}\text { Netflix - No ibero-american } \\
\text { titles } \\
\text { 1. El hoyo (Movie - Spain) } \\
\text { 2.Hogar (Movie - Spain) } \\
\text { 3. El silencio del pantano } \\
\text { (Movie - Spain) } \\
\text { 4. El practicante } \\
\text { (Movie - Spain) } \\
\quad \text { 5. Buenos dias, Verónica } \\
\text { (Series - Spain) } \\
\text { 6. El amor es ciego } \\
\text { (Reality- Chile) } \\
\text { 7.Jugando con fuego } \\
\text { (Reality- USA) } \\
\text { 8. El piso es lava } \\
\text { (Realty -USA) } \\
\text { 9. El Halloween de Hubie } \\
\text { (Movie - USA) } \\
\text { 10. La vieja guardia } \\
\text { (Movie - USA) } \\
\text { 11. Esta mierda me supera } \\
\text { (Series - USA) } \\
\text { 12. Proyecto power } \\
\text { (Movie - USA) }\end{array}$ & $\begin{array}{l}\text { Netflix }-\mathbf{N}^{\circ} \text { titles } \\
\text { 1. Shark Tank Season } 3 \\
\text { (Series - USA and Mexico) }\end{array}$ \\
\hline
\end{tabular}




\begin{tabular}{|l|l|l|}
\hline $\begin{array}{l}\text { NATIONAL } \\
\text { PREMIERE TITLES }\end{array}$ & \multicolumn{1}{|c|}{$\begin{array}{c}\text { IBERO-AMERICAN } \\
\text { PREMIERE TITLES }\end{array}$} & CO-PRODUCTIONS \\
\hline & $\begin{array}{l}\text { 13. Maldita } \text { (Series - USA) } \\
\text { 14. Locke \& Key } \\
\text { (Series - USA) } \\
\text { Claro TV - No ibero- } \\
\text { american titles } \\
\text { 1. Reto Tokio 2020 } \\
\text { (Series - Mexico) } \\
\text { HBO GO - No ibero- } \\
\text { american titles } \\
\text { 1. Murder on middle beach } \\
\text { (Series - USA) }\end{array}$ & \\
\hline Total: 7 & \begin{tabular}{l} 
Total: 16 \\
\hline GRAND TOTAL: 23
\end{tabular} & Total: 1 \\
\hline
\end{tabular}

Source: OBITEL Colombia

Out of a total of 26 series premiered in 2020 on VoD platforms, it was possible to show that seven national series were released: five on Netflix, with El robo del siglo being one of the most popular in Ibero-America and two series premiered on Caracol Play. The $\square$ Ibero-American premiere titles were 15: of which 13 were produced by Netflix, one by Claro Tv and one by HBO GO. Regarding co-productions between Colombia and other countries, no premiere results were found, while the premiere of a series co-produced between the USA and Mexico was found.

Consequently, the series premiered and most viewed in Colombia allow us to find that reality shows are a new form of consumption on VoD platforms. Table 7 shows 2020 releases in VoD by country of origin to assess the level of participation of the OBITEL countries. 
Table 7. VoD releases in 2020: countries of origin

\begin{tabular}{|l|r|r|}
\hline \multicolumn{1}{|c|}{ Country } & Titles & \multicolumn{1}{c|}{$\%$} \\
\hline $\begin{array}{l}\text { NATIONAL } \\
\text { TOTAL }\end{array}$ & 7 & $\mathbf{3 0 , 4 3 \%}$ \\
\hline $\begin{array}{l}\text { OBITEL } \\
\text { COUNTRIES } \\
\text { TOTAL }\end{array}$ & $\mathbf{1 6}$ & $\mathbf{6 9 , 5 6}$ \\
\hline Argentina & 0 & 0 \\
\hline Brazil & 0 & 0 \\
\hline Chile & 1 & $4,34 \%$ \\
\hline Colombia & 7 & $30,43 \%$ \\
\hline Ecuador & 0 & \\
\hline Spain & 5 & $21,73 \%$ \\
\hline USA & 9 & $39,13 \%$ \\
\hline Mexico & 1 & $4,34 \%$ \\
\hline Peru & 0 & 0 \\
\hline Portugal & 0 & 0 \\
\hline Uruguay & 0 & 0 \\
\hline Venezuela & 0 & 0 \\
\hline $\begin{array}{l}\text { TOTAL CO- } \\
\text { PRODUCTIONS }\end{array}$ & $\mathbf{1}$ & $\mathbf{4 , 3 4 \%}$ \\
\hline $\begin{array}{l}\text { Colombian co- } \\
\text { productions }\end{array}$ & 0 & $\mathbf{1 0 0}$ \\
\hline $\begin{array}{l}\text { Co-productions } \\
\text { between OBITEL } \\
\text { countries }\end{array}$ & 03 \\
\hline GRAND TOTAL & & \\
\hline
\end{tabular}

Source: OBITEL Colombia

Table 7 shows that the country's participation has a significant percentage in the production of content for VoD platforms, which allows us to recognize the expansion of these platforms in Ibero-Amer- 
ica. It was also possible to identify that by 2020 only Mexico and the US worked on a co-production for the region.

\section{Fiction and audience participation in digital environments}

In the midst of the pandemic, Decree 516 of April 4, 2020 was promulgated in Colombia by the Ministry of Information Technologies and Communications MINTIC, through which, measures are adopted for the provision of open television service broadcast, within the framework of the State of Economic, Social and Ecological Emergency of COVID 19, thereby reducing the national programming in television hours, through half the minimum number of hours that the channels must broadcast on their programming grill. With the above, private national television channels, which monopolize most of the audiences, stop producing current content and propose and carry out the repetition of fiction programs produced two decades ago such as the telenovela Pedro el Escamoso of the year 2001. Similarly, given the lack of current fiction production, emerging creations have been made that are independent of the content production companies, which are reproduced or transmitted by open access platforms such as YouTube, an example of this, is the Colombian web series "Aisla2 en cuarentena." These two examples are precisely those that will be considered to contemplate the analysis about the ways in which it was possible, on the side of the rerun, to generate conditions for an interaction with the audience amid a kind of normality of the digitization of the daily life and, on the other hand, the appearance of new bets within the context of the pandemic.

\subsection{Proposals for digital expansión}

Pedro el Escamoso, a telenovela broadcast by Caracol Televisión, contains 327 episodes with an approximate duration of two years, from April 19, 2001 to its last broadcast on February 21, 2003; the present retransmission started out on October 2020 via open signal 
television, which expands to the digital scene from a transmedia narrative such as interviews with the actors on web portals, where they allow the audience to visualize a comparative period of their old representations with their current daily life and activities; complete episodes in sequence or intermittence on social networks such as YouTube or Facebook; telenovela digital marketing; representations of the character in instant messaging as animated gifs or stickers; live videos on social networks or the spatialization of the soundtrack of the telenovela, El Pirulino, to platforms such as Spotify or YouTube.

In that order of ideas, the telenovela extends to social networks where the search for episodes can easily be found, without the need to follow a sequential narrative, which allows the audience to locate the desired episodes or to advance in the plot. In this scenario, the fiction is in several of the OTT (Over-The-Top) services that comprise content, services, or applications for users, including Spotify, in instant messaging such as WhatsApp and in social networks such as Tik Tok, Instagram, Twitter, YouTube and Facebook.

Thus, these digital extensions reflect or symbolize the main character of the fiction, Pedro Coral Tavera, played by the Colombian actor Miguel Varoni, who is a man of approximately 32 years old with the characteristics of a young village man who arrives in the capital from a small town in search of job opportunities, there he winds up working as a driver in an import company called Freydell and falls in love with his boss; thus, the fiction production incorporates particular elements of small towns that are transformed into a possible identity space of the nation, where the narrative of the fiction involves traditionalities or popular dailyities that represent situations, celebrations or characteristic profiles of the customs of a community in particular, such as popular beauty pageants, Colombia's national soccer team tshirt, support for the football team's fans, dialects and the construction of particular phrases of the character or of a colloquial nature, which have become viral such as masimo, mompirris, escamoso, fantoche, sagrado rostro, al peluche, among others. 


\subsection{Social interactivity}

From the point of view of the audiences, in the WhatsApp instant messaging service different users create static or animated images, about the fiction and its character, which are a communicative reference and carry an implicit message or with keywords of the character (masimo, sagrado rostro, mompirris, etc.) thus, the character is shown as a communicative icon in the gifs that complement the message to be emitted. Likewise, audiences are creators of funny images such as memes related to the character Pedro Coral that have gone viral not only on WhatsApp, but on social networks such as Facebook and Instagram. This way, the audiences of digital extension are prosumers, that is, they are consumers and creators of the content of the fiction made two decades ago, thus presenting an interactivity between the users who reference the telenovela.

Additionally, through social networks such as Tik Tok, a variety of videos are observed in relation to the plot, where users interact with fiction from different settings, among these, they upload videos of specific comic or picturesque scenes of the telenovela that impact or relate to the daily life of society. Likewise, users recreate the fictional characters in dolls with the physical characteristics of the actors, or personify the main character, using identical clothes or wigs to dance as Pedro el escamoso does with the renowned song "El pirulino", and there is also the creation of current videos where the actor, Miguel Varoni, dances like the character he imitated two decades ago. In relation to social networks such as Facebook, Instagram or Twitter, there are groups or profiles of the users of the telenovela, many of these created by the Caracol Channel, where episodes, anticipated previews, opinions and memes are shared. Along with this, the followers of the actors who played the fictional characters were strengthened in their social media. 


\subsection{Emerging fiction productions}

In Colombia, during mandatory confinement, media and the provision of open signal service constrained the null production of current fiction, for which Colombian actors and actresses executed a project independent of the media or private companies, through open access platforms such as the social network YouTube, an example of this is the Aisla2 en cuarentena web series.

Said story reflects moments of the new habits that society built from mandatory confinement, such as virtual encounters or appointments, work on digital platforms and sensations or emotions such as the loneliness, depression, joy, and anxiety that many people experienced due to the quarantine. Evidencing with this, elements, and tools of digital media to survive and respond to the needs of social encounters that were carried out physically or in person.

In relation to the interactions of the different users of the web series, from the YouTube channel Aisla2 en cuarentena, positive comments are observed towards the series, however, as the episodes came out, its audience decreased, so much so that the first chapter has 11,683 views and 436 likes, compared to the tenth and last chapter which contains 3,416 views and 163 likes, this shows the little advertising or digital marketing that was carried out on the web series, since it is not produced by private media which monopolizes the majority of audiences.

\section{The highlight of the year}

The social dynamics before and after the pandemic have changed in response to the current situation the world is going through, the appearance of a threat to health (COVID-19), which has consequently generated alterations in habits and behaviors of individuals. The new social habits that began as protection mechanisms, today are part of everyday life; referring to confinements, isolations, and quar- 
antines, are no longer novel terms, on the contrary, since the arrival of the virus they are part of our normality or, as it is currently known, "the new normal".

Before the pandemic, there was an offer of great variety of productions with different themes, among those, fictions that depicted current social problems in Colombia, such as: la Venganza de Analia, $\mathrm{Pa}^{\prime}$ Quererte and Enfermeras, the first production was intended to show cases of corruption linked to a social sphere such as politics; the second production, taught a reality that is not alien to any social stratum or circle, such as the difficulty in the construction of the family unit, from the point of view of the affective bond between parents and children and the obligations emanating from this bond; and in the third production, other situations that also afflict Colombians were highlighted, such as barriers to access to health care and job instability for healthcare workers.

As for the productions El General Naranjo and Betty la Fea, these probably failed to consolidate in the rating since their content was denser and of little reception for the new public, since their themes are framed in more unique contexts aimed at a specific audience.

With regards to productions such as Pedro el Escamoso and Pasión de Gavilanes, due to social restrictions and new events, productions that address peaceful content turn out to be spaces for inclusive family entertainment, aimed at a wide audience, of easy understanding, which has rescued audiences that would have been difficult to captivate in other times. All this because they are developed with humorous and pleasant plots and language which narrate situations that are far from reality, that captivate the viewer because they are unlikely dramas. On the other hand, it is no less important to note that there are other factors that have affected current programming since the pandemic started and it is the forced pause that new productions had between reality shows, dramatized shows, and telenovelas, for example, for the RCN and Car- 
acol channels, that due to the pandemic they were forced to stop their productions.

\section{Topic of the year: Fiction in times of pandemic}

In extraordinary times such as those currently being experienced because of the pandemic caused by COVID 19, not only are unexpected and difficult to assimilate situations arising throughout the world, but many of the processes that define social events seem to take on a different meaning or a much more complicated one than before. The world has changed, it is changing for better or for worse, and the only option that remains is to face with realism this dramatic challenge that continues to stretch over time and is clothed in multiple facets that continue to surprise us. It goes without saying that in this context of deep instability and uncertainty in all aspects of social life, as well as the mass media, television and all the component of fiction that circulates through this device, face in part a crisis and in part decisions both economic as in production to face the day to day and maintain or strengthen their contact with audiences.

Immersed for more than a year in this drastic alteration of the "normal" functioning of society due to the impact of the pandemic, very soon began to become evident a kind of contradiction between continuing economic activity on a regular basis to ensure the proper functioning and supply of the goods and services necessary for this purpose, and, on the other hand, the call to protect the health and life of people, to educate them in a set of habits and values around prevention and individual and collective care. This paradox, which initially seemed somewhat temporary and susceptible to negotiated solutions between the two factors, very soon became countries like ours, characterized by economic weakness and a historical fragility of the State and social policy, and also by the abundance of informality, poverty and the exclusion of broad layers of the population, became the day-to-day drama and the theme reiterated to the extreme by the permanent dis- 
course of the mass media, especially by television and by the presence and capacity of increasing influence of social networks.

As can be illustrated by the balance sheets and statements of the audiovisual industry sector, the negative impact of the pandemic meant practically a generalized halt in this productive sector, which is key to the functioning of society. The regime of isolation, quarantines and other restrictive measures for mobility and the meeting of groups, resulted in an atmosphere of passivity and enormous difficulty in producing and changing content, formats and programming at the usual pace, in addition to the financial crisis involved in this short circuit of productivity.

Apart from the personal dramas of individuals linked to the medium, as well as small and large producers in the face of the aforementioned crisis, it is also true that this industry found a very particular way to sustain itself and continue in its daily work: in some way the tragic news of every day in terms of disease, numbers, deaths, infections and recoveries, forecasts bordering on pessimism and measured optimism, became a business opportunity and also entertainment to implement a continuous and uninterrupted discourse about the heroism of surviving in the face of a pandemic as devastating as it is often portrayed in the media discourse.

The first axis of this television programming in times of pandemic has been anchored in the abundance of news from dawn to dusk, with which television, as a result of the permanence of millions of people in their homes, has returned to be that kind of company of daily life, that window through which the citizen, quite isolated in the confinement, is informed of the world and national reality, which due to the technological and media convergence of current information systems becomes the informal discourse that must be attended to in order to feel "informed", that is, "to feel as a participant in the problems facing humanity". 
It goes without saying that the tone of this continuous news program is admonitory, repetitive and focused on all the adverse effects of the disease and citizen behavior as the determining factor in the evolution of the virus, against which the State and its institutions are shown as the guarantors of order, health and care of the population. The causes that originate many of the "bad behaviors" of sectors of the population, in reference to the poorest sectors and excluded from the social pyramid, due to the labor informality they suffer, cannot stay in their "homes", these causes go unnoticed in the discourse and they do not appear as the problem they represent and that should act as a unifier not only of consensus but of real solutions on the part of the government in power.

In functional contrast to that daily tension of assuming the weight of the facts, the drama and the tragedy in which the country and its regions are added, and in which the people are just an intimidated, distressed, incapable and isolated spectator, in the face of the widespread fear of the eventual contagion and a tomorrow plagued by uncertainty, in the midst of the stress of this continuous isolation that already seems endless and that is usually represented as another frightening pandemic, television programming, stagnant due to the productive crisis of the sector, has made use of a resource that was clearly of incalculable symbolic and cultural value: the abundance of reruns in the prime time slots, which become the appropriate resource to make a catharsis in the audiences, to offer the soft and stimulating message, the space for relaxation and healthy family fun, and also the obsequious contents with which the consumer of this cultural industry can live evoking better times and feeding the hope that very soon things will change, return to normal and everything will start again.

Despite the difficult situation that has been indicated in relation to the audiovisual industry in the country as a result of the pandemic, it is also true, and it is also very important, that despite the pandemic itself, the audiovisual market in Colombia is being re- 
configured due to the expansion and arrival of the large transnational platforms that dominate the sector, which has implied both alliances with national channels and programmers as well as bids to obtain the longest and best times in the television medium, which was recorded in the debate and conflict that occurred recently as a result of the famous "screen quota".

In Colombia it is clear that we have long witnessed stiff competition between private channels for the dominance and control of the television medium, to which the call to more foreign competitors, platforms and streaming systems is added, which by intensifying the fight for audiences and greater economic and technological resources end up fortifying the market and keeping the industry and the medium current at the expense of greater consumption and, therefore, a greater incidence in terms of representativeness and acceptance of their messages and contents by the public. To illustrate this situation, it is worth mentioning the alliance between Netflix and Caracol, which allowed the former to dominate the supply of fiction content both on television and on demand (e.g. Pasión de Gavilanes) in this country, so that the latter flooded said platform with its own productions focused on series and narconovelas and on melodramatic productions assimilated to different emotional, affective, regional and national idiosyncratic aspects in which broad audiences meet, identify and enjoy said representations (e.g. Escobar el Patrón del mal, La ley secreta, La reina del Flow, among others).

In this new television media scenario, we continue to witness a reconfiguration of the agents that participate throughout the process of creation, production, distribution, and circulation of content that floods and dominates the national audiovisual market. These are alliances and other mechanisms that facilitate joint production, as indicated above, as well as the emergence of productive forms through which both the large platforms and the national channels and programmers seek to accommodate themselves in the current grids and formats of 
audiovisual offer to maintain and expand its share of presence, influence, and economic and symbolic profitability. Such is the case of the successful formula exploited by Netflix with Dynamo (national producer) in the making of El robo del siglo, which offered an alternative to the production of content with the large Colombian private channels, as well as in force agreements between national programmers and international paid channels such as FOX and HBO. This confirms the presence of a diverse panorama in the production of television fiction for the growing multiscreen systems in the nation and helps to account for the strong tensions that ensued with the legislative debate around the screen share quota of an entirely national production in prime time.

To refer in this section to the place and meaning of public television in the Colombian audiovisual environment we must register a situation that is not new, that sinks its roots in time, and on which depends the characterization that can be made of our public television.

In the first place, it is necessary to underline the fact that public television in this and other Latin American countries has been suffering decade after decade a kind of siege, isolation, and budget and political cuts, which has affected its performance and capacity to have a greater presence and influence in different audiences. This is no stranger to the desire to privatize that has dominated communication policy in the country in recent times to promote the presence of large private broadcasters and the arrival of pay-TV of transnational origin, as well as large platforms providing content in the audiovisual sector. A public television dwindling budget and often relegated to services of dissemination of content of educational, raizal, cultural type, which despite its importance for the different communities are subject to the structural limitations of this national public television.

Notwithstanding the foregoing, it must be recognized that there is an important community of filmmakers, users and facilitators in the country, around public television, so that this medium can remain active and current and can continue to be an enriching source of 
the social and cultural diversity of the nation and of the interests, principles and values around which an integrative social identity is sought, a recognition and a social and political visibility of the local, regional and the different, an integration of the communities to their past and their present reconfigured with the audiovisual resource. In this sense, it is worth highlighting the construction of the RTVC Play platform, a streaming system that groups different types of productions, going through fiction and the incursion into formats such as the web series (e.g. La de Troya), the transmedia narrative (e.g. Paciente) and productions in which narrative experimentation processes are carried out, without neglecting the management of reruns of high significance for the cultural heritage of the nation and its various communities (e.g. Crónicas de una generación trágica, Los pecados de Inés de Hinojosa, Dejémonos de vainas, etc).

In accordance with what has been stated in this section, it seems relevant to us to point out that in the face of the systematic cut of resources and support by successive governments to the national public radio and television system of Colombia, it is ignominious to see how the current government in its eagerness to " inform "equitably invests a multimillion dollar sum in the creation of an official newsletter that can only be beneficial to said government and the interests of the groups it represents, and instead to the detriment of offering to the population that cannot access other forms of use of the medium an information manipulated in accordance with the institutionalized discourse. 